Research. Two years later he was promoted to the post of deputy director and in 1923, on the retirement of Sir George Beilby, he became director of fuel research, a post which he held until 1931. Under his guidance the fuel research organisation undertook important investigations on the carbonization and gasification of coal and coke, on the production of oil from coal by hydrogenation, and on many other fuel problems. In association with the late Dr. F. S. Sinnatt, he organised and developed the Physical and Chemical Survey of the National Coal Resources. In recognition of his work as director of fuel research, Lander was made a C.B.E. in 1928.

In 1931 Lander returned to academic life as professor of mechanical engineering at the Imperial College of Science and Technology, London, a post which he held with distinction until 1946. Under his guidance, based on his broad experience and deep interest in education, a high standard in the training of mechanical engineers was achieved. He also played a prominent part in the systematic training of chemical engineers, and was the first chairman of the Board of Studies in Chemical Engineering in the University of London. The branch of research in which he was most keenly interested was that in relation to problems of heat transfer, on which he led and inspired teams of investigators for more than twenty-five years. His notable papers on the subject included that which he presented to the Institution of Mechanical Engineers in 1942, and for which he was awarded the Hawksley Gold Medal and Premium.

During the Second World War, Lander's experience and ability were invaluable. He played a great part in the development of gas turbines and jet propulsion, flame-throwers, and oil burners (F.I.D.O.) for the dispersion of fog over airfields. His merit in this kind of work lay not only in the way he guided and inspired investigators under his immediate control, but also in the facility with which he co-ordinated the work of several teams under different leaders and ensured harmonious co-operation from all in achieving results rapidly.

Of the many organisations indebted to him for advice and help, only a few can be mentioned as examples. He was for many years vice-chairman of the British National Committee of the World Power Conference, a member of the Safety in Mines Research Board, a member of the Mechanical Engineering Research Board of the Department of Scientific and Industrial Research, and chairman of several wartime scientific committees. For two years, 1946-48, he was president of the Institute of Fuel and was awarded the Melchett Medal of that Institute in 1945.

On retiring from the professorship of mechanical engineering at the Imperial College in 1946, he accepted an invitation to become dean of the Military College of Science at Shrivenham, with the task of re-organising the College as the principal establishment for training army officers in the military applications of science and technology. In this new sphere of activity, Lander had already achieved notable success. It was while he was engaged on this work that Lander died suddenly at Shrivenham on March 17.

Apart from his professional work, Lander had other interests, including music; and he had looked forward to spending more time at his house at Shepperton and with his motor launch on the Thames. Of a kindly nature, he will be missed by his many friends and colleagues.
IN October 1946, Dr. Lander became dean of the Military College of Science 7 he was re-assembling after the War at Shlukath in Wiltshire and was expanding its scop to prepare officer students for external degreds in science and engineering of the Universify wo London as well as to train officers for the technical staff of the Army.

buif re-organisation necessary to enable the College t6 calry out these extended functions at the same time as it was being reconstituted involved an enormous amount of work in the remoulding of the faculties, in discussions with the University of London, in the preparation of syllabuses and in the recruitment of lecturing staff. The co-ordination of this work in the College fell upon Dr. Lander, and his energy and enthusiasm and his connexions with the University contributed in great degree to the reconstitution of the College. That within two and a half years of its re-opening the first technical staff course passed out and the first degree courses took Part I of their degrees at London was largely due to his untiring work:

His wide contacts with the academic world resulted in the best of advice being available to the College, and his strong support of a policy of insistence upon high academic standard has laid sound foundations for the future.

Apart from his work on the academic side, Dr. Lander was a keen supporter of the sports and cultural activities of the College. $\mathrm{He}$ was a leading performer in the Musical Club and led the College orchestra.

But the quality by which he will be most remem. bered in the College was his kindly wisdom. In an assembly of soldier students and of academic and soldier teachers, most problems are viewed from several points of view and divergent opinions are strongly held. That varying opinions have been reconciled and canalized into channels which furthered the objects of the College has been in no small degree due to Dr. Lander's unfailing wisdom. His counsel both in wider policy and in day-to-day detail was invaluable, and the Military College of Science will look back on its first dean, with feelings of gratitude and deep affection, as one of the main founders of its modern constitution.

W. J. ELDRIDGE

\section{Mr. H. E. Hadley}

Mr. H. F. HADLEY, well known as the author of many elementary text-books of physics, died on March 6, at the age of eighty-two. Mr. Hadley had lived rather a retired life. He was appointed head. naaster of a small science school in Kidderminster, where he combined with physics a lectureship in chemistry. In those days, physics was considered of less importance than chemistry; but Mr. Hadley was always at heart a physicist. In spite of the almost total lack of physical apparatus, he made physics the career of three of his early pupils, for in three successive years his students gained national scholarships at the Royal College of Science, London, now the Imperial College of Science and Technology, a rather unique success for a small school.

Mr. Hadley was a contemporary of Sir Richard Gregory and H. G. Wells at the same College, and from his training there and association with C. V. Boys he acquired a special genius for making his own physical apparatus. His teaching equipment at Kidderminster was largely of his own making, 
and it would seem that this gave physies an added attraction to his students. Evidence of his ingenuity in this direction is apparent in his books.

In 1898 he wrote his first text-book, on "Magnetism and Electricity for Beginners". This was the first of several text-books produced in association with Sir Richard Gregory, which are known to generations of physics students. Much of his time thenceforward was devoted to the preparation of these books, while he still continued his teaching, from which he only recently retired after a period of more than fifty years. He maintained his interest in his books to the end, devoting much care to keeping them abreast of modern developments.
Mr. Hadley had a charming personality, and he was regarded with affection by those who benefited from his instruction.

W. S. TUCKER

WE regret to announce the following deaths :

Mr. Will Hay, well known as an actor and also a distinguished amateur astronomer, on April 18, aged sixty.

Mr. R. A. 'Todd, a Ministry of Agriculture and Fisheries inspector and formerly a member of the staff of the Plymouth Laboratory of the Marine Biological Association of the United Kingdom.

\section{NEW S}

\section{Meldola Medal for 1948 : Dr. R. A. Raphael}

ON the prommendation of the Council of the Royal Institute of Chemistry, the Society of Maccabæans has awarded the Meldola Medal for 1948 to Dr Ralph Alexander Raphael, in recognition of the contributions he has made to the investigation of new methods of approach to the synthesis of natural compounds. Dr. Raphael graduated in 1941 from the Imperial College of Science and Technology with first-class honours in chemistry, and in 1943 was awarded a Ph.D. for work on acetylenic compounds. During 1943-46 he was head of one of the chemotherapeutic research departments of Messrs. May and Baker, Ltd., and was mainly concerned with penicillin chemistry. He was then awarded an Imperial Chemical Industries fellowship and resumed research work at the Imperial College on the investigation of the potentialities of acetylenic compounds in the synthesis of natural products. In 1947 this work resulted in the total synthesis of the penicillic acid, thus proving its structure beyond doubt. Attention was then turned to the utilization of the peculiar properties of acetylenic compounds to accomplish the synthesis of carbohydrates and their derivatives, and, up to the present, arabitol, ribitol, erythritol, threitol and erythrulose have been obtained. A study is also being made of methods of producing long-chain aliphatic acids of various types. Concurrently, Dr. Raphael is also investigating synthetic routes to compounds containing the vitamin $\mathrm{D}$ triene system. $\mathrm{He}$ has recently been appointed lecturer in organic cheppistry in the University of Glasgow.

\section{Avemue of Human-headed Sphinxes at Luxor}

IT has long beenknown that the avenue of ram. headed sphinxf of Amenophis III which extends southwards $7.0 \mathrm{~m}$ the Temple of Khons at Karnak is the nontform end of a processional way once linking the Thinple of Karnak with the Temple of Luxor aroft one and a half miles to the south. On the IIne ff this avenue, Zakaria Effendi Ghoneim, chief inspector of antiquities for Upper Egypt, has recently found a further series of human-headed sphinxes erected by either Nectanebo I or II about a thousand years later, in the late fourth century B.c. The main interest of the new discovery appears to lie, for the moment at least, in the inscriptions on the base of each sphinx. The text records that Nectanebo had "made this road for Amun so that he might make good navigation from Luxor". The god Amun was normally resident at Karnak. The principal occasion

\section{nd VIEW S}

on which he visited Luxor was during the annual festival of Opet, when he was conveyed by river from Karnak to Luxor and the whole city was given over to festivity for many days. The new texts, therefore, either hint that by the end of the Pharaonic period the river journey of Amun during the Feast of Opet had been replaced by a progress by land, or they refer to a new or unidentified Theban feast. As the clearance and excavations round the Temple of Luxor progress, there is every reason to expect that new discoveries will be made, and that fresh light will be thrown on the early history of Thebes.

\section{Additional Remains of Australopithecus in South Africa}

Further discoveries $9 f$ th/e remains of the fossil Australopithecinæ of Sfot Africa are now reported from a new it drakapansgat, almost 250 miles north of Sterfoutein, where Dr. R. Broom found numbers if skulls and portions of the limb skeleton dugygh 947 and 1948. Two of the Makapansgat spetimens, which have already been described by Hrof. R. Dart in the American Journal of Physical Anthropology $(6,259$ and 391 ; 1948) and referred by him to a new species, $A$. prometheus, consist of an occipital bone and an immature mandible. These provide additional confirmation of the inferences based on the earlier material that the Australopithecinæ show in certain anatomical features a remarkable approximation to those hitherto regarded as distinctive of the Hominidæ. For example, the disposition and extent of the nuchal crest and muscular markings on the occipital bone conform to the human rather than the simian type. The perfectly preserved and unworn anterior premolar in the immature mandible is bicuspid with the cusps of approximately equal height as in man, and thus differs markedly from the characteristic sectorial form of the lower anterior premolar in the anthropoid apes. Still more recently, there have been found at the same site a considerable part of the facial skeleton, a parietal bone, and the iliac portion of a pelvis. According to unpublished reports, the ilium, like the specimen already described by Broom (Nature, 160, $430 ; 1947)$, is closely similar in shape and proportions to a human ilium, and thus contrasts strongly with that of apes.

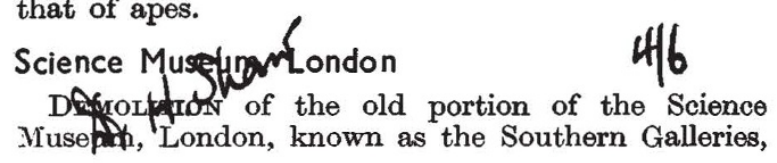

